\title{
PENGARUH MODEL PEMBELAJARAN TERHADAP KEMAMPUAN MEMECAHKAN MASALAH LINGKUNGAN HIDUP PADA SISWA YANG MEMPUNYAI HASIL BELAJAR IPA TINGGI DI SEKOLAH DASAR \\ (Studi Eksperimen Terhadap Siswa SD Laboratorium UPI \\ Kampus Cibiru)
}

\author{
Dede Margo Irianto ${ }^{1}$
}

\begin{abstract}
ABSTRAK
The aim of the research is to identify the influence of learning model and IPA Science learning on the ability to solve problem in learning environmental education at the elementary school. This research was conducted in SD Laboratorium UPI Kampus Cibiru Bandung. Experimental method with factorial plan $2 x 2$ is the method that was employed in this study. The sampling objects were 40-fourth grade students. Twenty of them achieved high learning outcomes in environmental study meanwhile the remains were having low learning outcomes. Two ways varian analysis (ANAVA) was used in hypothesis test and then continued by Turkey test. The research conclusion were: Students with high learning outcomes in science had better ability to solve environmental problems using constructivist learning model than interactive learning model;
\end{abstract}

Keywords : constructivist model of learning, interactive model of learning, environmental problem, science learning outcomes

\section{A. PENDAHULUAN}

Banyak fenomena berkaitan dengan penurunan kualitas lingkungan yang nampak di sekitar, menyadarkan kita bahwa penurunan kualitas lingkungan memang sedang terjadi dengan kecepatan yang sangat mengkhawatirkan. Ada beberapa indikator yang menunjukkan terjadinya penurunan kualitas lingkungan, yaitu pencemaran dan limbah, berkurangnya sumber energi di alam yang dapat dimanfaatkan, terjadinya degradasi lahan, berkurangnya keanekaragaman hayati, dan makin berkurangnya sumber daya air.

Merosotnya kualitas lingkungan yang dapat kita lihat dan kita rasakan sekarang ini, menuntut adanya tindakan yang harus sesegera mungkin dilaksanakan. Tindakan ini diperlukan agar kita dapat mencegah terjadinya kemerosotan kualitas lingkungan yang terus menerus, yang pada akhirnya dapat menjadi bencana yang menyengsarakan kita semua.

Salah satu aksi lingkungan yang dilaksanakan dalam bentuk class action adalah berupa program pendidikan lingkungan. Program ini dirasakan dan dinyatakan sebagi program pendidikan yang berperan dalam mengembangkan literasi lingkungan pada diri individu. Sebagai langkah awal pengembangan literasi lingkungan, pendidikan lingkungan mencoba memberikan pengetahuan dan pemahaman tentang isu-isu dan permasalahan; konsep serta prinsip-prinsip yang

\footnotetext{
${ }^{1}$ Dosen UPI Kampus Cibiru
} 
terjadi di lingkungan. Undang-undang Republik Indonesia Nomor 23 tahun 1997 tentang lingkungan hidup, pasal 9 menyatakan bahwa pemerintah berkewajiban menumbuhkembangkan kesadaran masyarakat pada tanggung jawabnya dalam pengelolaan lingkungan hidup. Hal ini dapat dijadikan sebagai landasan untuk melaksanakan tindakan perbaikan terhadap merosotnya kualitas lingkungan, yaitu melalui jalur pendidikan. Dalam hal ini melalui usaha pendidikan yang dilaksanakan sejak usia dini di taman kanak-kanak dan sekolah dasar melalui pemberlakuan mata pelajaran pendidikan lingkungan hidup.

Masih belum efektifnya pelaksanaan pembelajaran Pendidikan Lingkungan Hidup, di antaranya adalah karena para guru Pendidikan Lingkungan Hidup belum menerapkan pendekatan dan metode pembelajaran yang variatif dan cocok untuk pelaksanaan pembelajaran Pendidikan Lingkungan Hidup. Dari hasil pengamatan peneliti terhadap pelaksanaan pembelajaran Pendidikan Lingkungan Hidup terutama di sekolah dasar. Nampak bahwa kegiatan pembelajaran lebih banyak bersifat teoritis dan tidak terlalu menuntut siswa untuk secara praktis dan aplikatif menerapkan apa yang diperoleh dalam pembelajaran Pendidikan Lingkungan Hidup untuk memecahkan permasalahan lingkungan yang dihadapinya dalam kehidupan sehari-hari.

Model pembelajaran konstruktivis dan model pembelajaran interaktif merupakan dua model pembelajaran yang dapat digunakan pada proses pembelajaran di tingkat pendidikan dasar, termasuk dalam pembelajaran Pendidikan Lingkungan Hidup. Tetapi dalam pelaksanaannya, guru jarang menggunakan model-model ini dalam pembelajaran sehari-hari.

Pada dasarnya sasaran dari proses pendidikan adalah siswa. Setiap siswa merupakan individu yang unik. setiap siswa memiliki karakteristik, sifat dan potensi yang berbeda satu sama lain. Siswa merupakan seseorang yang sedang berkembang yang memiliki potensi tertentu dan dengan bantuan pendidik ia dapat mengembangkan potensinya secara optimal. Pendidikan adalah proses yang membuat siswa melakukan kegiatan belajar sesuai dengan rancangan. Rancangan pembelajaran yang dibuat oleh guru harus dapat memfasilitasi potensi. Salah satu kebutuhan yang sangat esensial bagi siswa adalah dapat memecahkan permasalahan yang dihadapi dalam kehidupan sehari-hari, terutama permasalahan yang berkaitan dengan lingkungan.

Permasalahan lingkungan dapat meliputi aspek-aspek yang menjadi indikator merosotnya kualitas sumber daya kehidupan pada kegiatan masa lalu, saat ini dan prospek bagi kehidupan di masa yang akan datang. Aspek permasalahan lingkungan itu adalah pencemaran dan limbah, energi, degradasi lahan, keanekaragaman hayati, dan sumber daya air.

Jadi kemampuan memecahkan masalah lingkungan adalah suatu kecakapan dalam membuat alternatif pemecahan masalah lingkungan yang berkaitan dengan pencemaran dan limbah, energi, degradasi lahan, keanekaragaman hayati, dan sumber daya air.

Ilmu Pengetahuan Alam (IPA) merupakan ilmu pengetahuan tentang alam semesta dengan segala isinya yang didapatkan melalui suatu proses untuk memperoleh kebenaran. Pendidikan IPA khususnya di sekolah dasar diharapkan 
dapat menjadi wahana bagi siswa untuk mempelajari diri sendiri dan alam sekitar, serta pengembangan proses lebih lanjut dalam menerapkannya di dalam kehidupan sehari-hari. Proses pembelajarannya menekankan pada pemberian pengalaman secara langsung untuk mengembangkan kompetensi dengan cara menjelajahi dan memahami alam sekitar secara ilmiah. Melihat uraian di atas, maka terlihat adanya hubungan yang sangat erat antara IPA dengan Pendidikan Lingkungan Hidup. Bahkan dalam kenyataannya di lapangan yang umumnya dipercaya untuk menjadi guru Pendidikan Lingkungan Hidup adalah guru IPA.

Jadi di samping penggunaan model pembelajaran yang tepat dan bervariasi, untuk mengoptimalkan kemampuan siswa dalam memecahkan masalah-masalah lingkungan dalam pembelajaran Pendidikan Lingkungan Hidup di sekolah dasar, juga diperlukan konsep-konsep IPA yang relevan sehingga siswa dapat mencapai tujuan pembelajaran Pendidikan Lingkungan Hidup yaitu memecahkan permasalahan yang berkaitan dengan lingkungan hidup dalam kehidupan seharihari.

Berdasarkan uraian di atas, kiranya menjadi menarik untuk dikaji melalui suatu penelitian, bagaimana pengaruh model pembelajaran konstruktivis dan model pembelajaran interaktif dan hasil belajar IPA siswa dalam mengembangkan kemampuan memecahkan masalah lingkungan hidup dalam pembelajaran Pendidikan Lingkungan Hidup di sekolah dasar.

Berdasarkan latar belakang masalah yang telah diuraikan di atas, maka masalah dalam penelitian ini dapat dirumuskan sebagai berikut "Apakah terdapat perbedaan pengaruh antara model pembelajaran konstruktivis dan model pembelajaran interaktif terhadap pengembangan kemampuan memecahkan masalah pada siswa yang mempunyai hasil belajar IPA tinggi dalam pembelajaran Pendidikan Lingkungan Hidup di sekolah dasar?

\section{B. TINJAUAN PUSTAKA}

\section{Kemampuan Memecahkan Masalah dalam Lingkungan Hidup}

a. Hakikat Pemecahan Masalah

Proses pembelajaran memiliki tujuan yaitu membantu siswa dalam perkembangan tertentu, yang pada akhirnya tujuan utamanya adalah membantu siswa memecahkan permasalahan di dalam hidupnya. Termasuk di antaranya adalah permasalahan yang dihadapi oleh siswa yang berkaitan dengan lingkungan hidupnya.

Masalah adalah suatu situasi yang dialami oleh seseorang, sehingga apa yang dialaminya berbeda dengan apa yang secara ideal diinginkannya. Heylighen (http://www, 2002).Seseorang disebut mempunyai masalah apabila ada pemisah antara keadaannya dengan apa yang diinginkannya dan dia tidak tahu bagaimana menghilangkan pemisah tersebut. Suatu masalah dapat dipecahkan dengan berbagai metode sesuai dengan konteks masalah tersebut.

\section{b. Permasalahan Lingkungan Hidup}

Permasalahan lingkungan hidup muncul karena adanya kemunduran kualitas lingkungan. Berdasarkan apa yang telah diuraikan di atas, maka permasalahan 
lingkungan hidup berkembang dari penurunan kualitas lingkungan. Chiras mengemukakan bahwa permasalahan lingkungan dapat meliputi aspek-aspek yang menjadi indikator menurunnya kualitas sumber daya kehidupan pada kegiatan masa lalu, saat ini, dan prospek bagi kebutuhan di masa datang. Aspek permasalahan lingkungan itu adalah pencemaran dan limbah, energy, degradasi lahan, keanekaragaman hayati, dan sumber daya air (Chiras. 1996)

Berdasarkan uraian di atas, maka yang dimaksud dengan kemampuan memecahkan masalah lingkungan adalah suatu kecakapan dalam membuat alternative pemecahan masalah lingkungan yang berkaitan dengan pencemaran dan limbah, energy, degradasi lahan, keanekaragaman hayati, dan sumber daya air.

\section{Model Pembelajaran dalam Pendidikan Lingkungan Hidup}

a. Hakikat Pembelajaran

Pembelajaran adalah terminologi yang digunakan untuk menggambarkan proses yang meliputi perubahan melalui pengalaman. Proses perubahan tersebut secara relatif untuk memperoleh perubahan yang permanen meliputi : pengertian, pemahaman, sikap, pengetahuan, informasi, kemampuan dan keterampilan melalui pengalaman (Thomas L Good \& Jere B, 1990)

Kegiatan pembelajaran juga merupakan suatu sarana dalam pemberian bekal bagi siswa untuk dapat berperan di masa mendatang.

Dari beberapa definisi yang telah diuraikan di atas, maka dalam penulisan ini, pembelajaran diartikan sebagai usaha sadar dan aktif yang dilakukan seseorang terhadap lingkungannya atau materi pembelajaran melalui proses aktivitas mental ataupun fisik untuk memperoleh pengetahuan dan keterampilan yang dapat bertahan relatif lama. Dengan kata lain pembelajaran adalah proses proses perubahan tingkah laku pada diri seseorang pada satuan waktu tertentu, yang ditandai dengan perubahn tingkah laku, sebagai hasil pembelajaran.

\section{b. Pendidikan Lingkungan Hidup}

Menurut UNESCO Pendidikan lingkungan Hidup (environmental education $E E)$ adalah suatu proses untuk membangun populasi manusia di dunia yang sadar dan peduli terhadap lingkungan total (keseluruhan) dan segala masalah yang berkaitan dengannya, dan masyarakat yang memiliki pengetahuan, ketrampilan, sikap dan tingkah laku, motivasi serta komitmen untuk bekerja sama, baik secara individu maupun secara kolektif, untuk dapat memecahkan berbagai masalah lingkungan saat ini, dan mencegah timbulnya masalah baru

Pada saat ini pendidikan lingkungan secara nyata dipandang sebagai pendidikan ekologi dengan mempertimbangkan kebutuhan manusia. Artinya pendidikan lingkungan dipandang sebagai kemahiran memahami dan menerapkan prinsip-prinsip ekologi lingkungan alam, ekologi manusia, proses-proses sosioekonomi serta biofisik pada situasi nyata untuk mengatasi permasalahan lingkungan. Pendidikan lingkungan ditempatkan dalam bidang studi tertentu yaitu IPA dan IPS, lebih banyak dipandang secara holistik dan interdisipliner.

Pendidikan Lingkungan menuntut individu mengetahui dan memahami permasalahan di sekitarnya. Dalam proses ini pendidikan lingkungan dipandang 
sebagai aktivitas belajar individu agar peduli terhadap lingkungan. Aktivitas belajar tersebut mencakup pengembangan pengetahuan, kesadaran, sikap, keterampilan, dan nilai-nilai yang memungkinkan individu dan masyarakat mendukung ke arah memelihara serta meningkatkan mutu lingkungan. Aktivitas belajar dikembangkan mengacu pada situasi daerah yang spesifik secara lokal, regional, dan global (Rush et al, 1999)

\section{c. Pembelajaran Pendidikan Lingkungan Hidup}

Lieberman dan Hoody (1998) menyatakan bahwa pendidikan lingkungan telah menjadi pelopor dalam mendorong pendidikan interdisipliner, pemikiran kritis dan pemecahan masalah. Salah satu bentuk pendekatan dalam pembelajaran pendidikan lingkungan adalah pendekatan secara menyeluruh yang mencakup : 1) menawarkan cara yang efektif untuk mengintegrasikan kurikulum, 2) mengembangkan keterampilan berpikir kreatif dan kritis, 3) mengembangkan keterampilan riset untuk membantu memecahkan masalah bagi siswa, 4) menyelidiki sikap dan nilai-nilai antar budaya, 5) melibatkan berbagai kecerdasan, 6) melibatkan siswa dalam masyarakat, 7) menggunakan strategi pembelajaran yang berpusat kepada siswa sehingga siswa terlibat secara aktif dalam proses belajar.

Dalam melaksanakan pembelajaran lingkungan hidup seperti diuraikan di atas, maka diperlukan model pembelajaran yang tepat. Model pembelajaran sering pula diistilahkan dengan strategi pembelajaran atau strategi belajar mengajar. Bruce Joyce dan Marsha Weil (1986) menyebutkan bahwa strategi belajar mengajar adalah sebagai Models of Teaching. Yang dimaksud dengan Teaching di sini adalah suatu upaya membantu siswa untuk mencapai tujuan belajarnya, sedangkan Models adalah rencana atau pola umum. Dengan demikian jelaslah bahwa model mengajar adalah suatu rencana atau pola umum dalam kegiatan belajar mengajar yang ditujukan untuk membantu siswa mencapai tujuan belajarnya.

Dalam pembelajaran Pendidikan Lingkungan Hidup di sekolah dasar, model pembelajaran atau strategi belajar mengajar ini sangat penting untuk dikuasai oleh guru. Dengan penguasaan strategi belajar mengajar yang beragam maka seorang guru dapat membantu siswa untuk mencapai tujuan belajarnya, yang pada dasarnya merupakan langkah awal untuk membuat siswa tersebut menjadi seorang manusia yang peka dan peduli terhadap lingkungan sekitarnya.

\section{d. Model Pembelajaran Konstruktivis}

Istilah konstruktivisme tentang belajar berasal dari Giambattista Vico pada awal abad ke-18 yang mempertanyakan mengenai konsep ilmu pengetahuan sebagai tujuan. Vico menjadi dikenal melalui Piaget yang mengatakan "knowledge is constructed in the mind of the learner", sebagai suatu proses yang aktif dibandingkan proses yang pasif (Tobias, S and Hand, B, 1992). Proses tersebut ialah ketika siswa dapat membangun pengetahuan awal secara teratur dan bermakna setahap demi setahap. Ilmu pengetahuan dapat dipahami sebagai sesuatu yang harus dibangun untuk dan oleh siswa sendiri. Karena itu penalaran yang berkembang dalam pikiran seorang individu (guru) tidak dapat dipindahkan begitu saja ke individu yang lain/siswa (Tobias, S and Hand, B, 1992) 
Berdasarkan pandangan di atas, jelaslah bahwa model pembelajaran konstruktivis adalah model yang menekankan pada pengetahuan awal siswa sebagai tolak ukur dalam belajar. Model kontruktivis merupakan salah satu pandangan tentang proses pembelajaran yang menyatakan bahwa dalam proses belajar, perolehan pengetahuan diawali dengan terjadinya konflik kognitif. Konflik kognitif muncul saat terjadi interaksi antara pengetahuan awal yang telah dimiliki oleh siswa dengan fenomena baru yang tidak dapat dipadukan begitu saja, sehingga diperlukan perubahan dan modifikasi struktur untuk mencapai keseimbangan. Peristiwa tersebut akan terus berkelanjutan selama siswa menerima pengetahuan baru.

\section{e. Model Pembelajaran Interaktif}

Salah satu tujuan dari program pendidikan lingkungan di sekolah dasar adalah untuk membentuk sikap dan kepribadian yang positif dalam bentuk kegiatan, pembiasaan pola hidup yang menghargai lingkungan, membina kemampuan berinisiatif dan mengambil keputusan yang tepat dalam waktu singkat, yang salah satu di antaranya diwujudkan dengan menanamkan sikap ingin tahu pada siswa (Disdik Kota Bandung, 2008). Perasaan ingin tahu siswa itu di antaranya ditunjukkan oleh pengajuan pertanyaan-pertanyaan yang dikemukakan oleh siswa. Akan tetapi seperti dikemukakan oleh Biddulph(1990) beberapa praktek pengajaran cenderung menghambat "pengajuan pertanyaan" siswa.

Model pembelajaran interaktif adalah suatu pendekatan khusus yang meliputi kemampuan dan pertimbangan atas pertanyaan-pertanyaan siswa sebagai ciri sentral. Dengan kata lain dalam proses pembelajaran tersebut siswa akan bertanya dan kemudian melakukan penyelidikan tentang pertanyaan mereka sendiri( Bell, 1993).

Model pembelajaran interaktif adalah suatu model pembelajaran yang merujuk pada pandangan konstruktivisme. Model pembelajaran ini sering dikenal sebagai model "pertanyaan siswa". Pada model ini, guru berusaha untuk menggali pertanyaan siswa. Jadi siswa ditantang rasa ingin tahunya terhadap obyek yang sedang dipelajari dengan cara mengajukan pertanyaan. Kemudian siswa melakukan penyelidikan atas pertanyaan mereka sendiri.

\section{Hakikat Ilmu Pengetahuan Alam}

IPA berhubungan dengan cara mencari tahu tentang alam secara sistematis, sehingga IPA bukan hanya penguasaan kumpulan pengetahuan yang berupa faktafakta, konsep-konsep atau prinsip-prinsip saja tetapi juga merupakan suatu proses penemuan. IPA diperlukan dalam kehidupan sehari-hari untuk memenuhi kebutuhan manusia melalui pemecahan-pemecahan masalah yang dapat diidentifikasikan. Penerapan IPA perlu dilakukan secara bijaksana agar tidak berdampak buruk terhadap lingkungan.

Yuliaritiningsih dan Irianto (2008) mengemukakan hakikat IPA yang dapat dikategorikan ke dalam dua dimensi yaitu (1) Dimensi produk, IPA merupakan kumpulan hasil kegiatan empirik (fakta-fakta) dan kegiatan analitik (data, konsep, prinsip, dan teori) yang dilakukan oleh para ilmuwan selama berabad-abad. Terdapat tiga kriteria bagi suatu produk IPA yang benar. Ke tiga kriteria tersebut 
adalah mampu menjelaskan fenomena yang telah diamati atau telah terjadi, mampu memprediksi peristiwa yang akan terjadi, dan mampu diuji dengan eksperimen sejenis. (2) Dimensi proses. IPA merupakan cara kerja, cara berpikir dan cara memecahkan masalah. Pengertian ini ditandai dengan menggunakan keterampilan proses untuk mempelajari suatu materi. Keterampilan proses dalam IPA memiliki kerangka dasar prosedur yang dapat dijabarkan dalam enam langkah yaitu mengobservasi, memprediksi, menginterpretasi, merancang dan melakukan eksperimen, mengendalikan variable, merumuskan hipotesis, dan menarik kesimpulan. Selain itu, IPA juga memiliki dimensi yang tidak kalah penting yaitu (3) dimensi sikap.

Bagaimana peranan IPA dalam Pendidikan Lingkungan Hidup dipaparkan oleh A.M. Lucas (1980 yang menyatakan :

"Science is seen as a vehicle for promoting environmental education, sometimes the central activity and some times as a component of environmental education; The environmet may provides an organizing themes in science courses; and there are examples of environmental education providing a vehicle for developing themes about science, particularly as a method of demonstrating or discussing the social relevance of science or the social responsibility of scientist"

Berdasarkan uraian di atas, nampak bahwa IPA sangat diperlukan dalam pengembangan kemampuan memecahkan masalah yang dihadapi oleh serang peserta didik dalam hidupnya, termasuk kemampuan memecahkan masalah lingkungan.

\section{Penelitian yang Relevan}

Ada beberapa penelitian yang relevan dengan penelitian ini, antara lain penelitian tentang pelaksanaan pengajaran PKLH SD Jawa Barat (Marsidi, 1998) yang menemukan bahwa kemampuan guru dalam melaksanakan pengajaran PKLH masih harus ditingkatkan, agar dapat mempersiapkan generasi mendatang sesuai dengan pembangunan yang berkelanjutan. Penelitian yang lain menemukan bahwa model pengelolaan pembelajaran yang dikembangkan cukup efektif untuk meningkatkan perkembangan dan kesiapan intelektual dan sosial, namun belum mampu meningkatkan perkembangan dan kesiapan intelektual serta belum mampu meningkatkan perkembangan dan kesiapan intelektual dan sosial personal (Sunaryo Kartadinata, 1990). Untuk itulah diperlukan suatu model pengelolaan pembelajaran yang mampu mengembangkan kecerdasan majemuk kepada siswa. Penelitian lain yang dilakukan menunjukkan bahwa penggunaan model pembelajaran konstruktivis dapat meningkatkan aktivitas belajar siswa(Resti oktavianti, 2010). Hasil penelitian lain menunjukkan bahwa setiap siswa memiliki multikecerdasan. Perkembangan kecenderungan kecerdasan tersebut berbeda-beda dalam setiap individu siswa (Ria Mey Wulan, 2010). Hasil penelitian lain menunjukkan bahwa strategi pembelajaran lingkungan dan konsep dasar ekologi yang dikuasai oleh siswa ternyata berpengaruh terhadap kemampuan siswa dalam memecahkan masalah lingkungan (Irma Wardhany, 2006) 


\section{METODE PENELITIAN}

Penelitian ini dilakukan di SD Laboratorium UPI Kampus Cibiru dengan menggunakan metode eksperimen. Dalam penelitian ini, variabel bebas (variabel eksperimen) yang menjadi ruang lingkup penelitian adalah: (1) model pembelajaran konstruktivis, (2) model pembelajaran interaktif. Variabel terikat (variabel tercoba) adalah Kemampuan memecahkan masalah yang berkembang dalam pembelajaran Pendidikan Lingkungan Hidup di sekolah dasar. Sedangkan sebagai variabel atribut adalah hasil belajar IPA, yang terdiri dari (1) hasil belajar IPA tinggi dan (2) hasil belajar IPA rendah.

Adapun rancangan penelitian yang digunakan adalah rancangan faktorial bertingkat dua atau rancangan faktorial $2 \times 2$ sebagai berikut :

Tabel 1

Rancangan Faktorial $2 \times 2$

\begin{tabular}{|c|c|c|c|c|}
\hline \multirow{2}{*}{\multicolumn{2}{|c|}{ Variabel $X_{1}$}} & \multicolumn{3}{|c|}{ Model Pembelajaran ( A ) } \\
\hline & & \multicolumn{2}{|c|}{ Konstruktivis } & \multirow{2}{*}{$\begin{array}{l}\text { Interaktif } \\
\mathrm{A}_{2} \mathrm{~B}_{1}\end{array}$} \\
\hline Hasil belajar IPA (B) & Tinggi $\left(B_{1}\right)$ & $\mathrm{A}_{1} \mathrm{~B}_{1}$ & $>$ & \\
\hline & Rendah $\left(B_{2}\right)$ & $\mathrm{A}_{1} \mathrm{~B}_{2}$ & $<$ & $\mathrm{A}_{2} \mathrm{~B}_{2}$ \\
\hline \multicolumn{2}{|l|}{ Interaksi } & \multicolumn{3}{|l|}{$\mathrm{A} \times \mathrm{B}$} \\
\hline
\end{tabular}

$\mathrm{A}_{1}=$ Kelompok siswa dengan perlakuan model pembelajaran konstruktivis secara keseluruhan

$\mathrm{A}_{2}=$ Kelompok siswa dengan perlakuan model pembelajaran interaktif secara keseluruhan

$\mathrm{B}_{1} \quad=$ Kelompok siswa yang memiliki hasil belajar IPA tinggi

$\mathrm{B}_{2} \quad=$ Kelompok siswa yang memiliki hasil belajar IPA rendah

A1B1 = Kelompok siswa yang memiliki hasil belajar IPA tinggi dengan perlakuan model pembelajaran konstruktivis.

$\mathrm{A} 2 \mathrm{~B} 1$ = Kelompok siswa yang memiliki hasil belajar IPA tinggi dengan perlakuan model pembelajaran interaktif.

A1B2 = Kelompok siswa yang memiliki hasil belajar IPA rendah dengan perlakuan model pembelajaran konstruktivis

A2B2 = Kelompok siswa yang memiliki hasil belajar IPA rendah dengan perlakuan model pembelajaran interaktif

Populasi terjangkau dalam penelitian ini adalah siswa kelas 4 SD laboratorium UPI Kampus Cibiru yang memiliki hasil belajar IPA tinggi dan hasil belajar IPA rendah.

Pengumpulan data dilakukan dengan menggunakan instrumen kemampuan memecahkan masalah yang berkembang dalam pembelajaran pendidikan lingkungan hidup, diperoleh melalui tes, dengan alat ukur yang secara khusus dikembangkan oleh peneliti. Sebelum instrumen digunakan, terlebih dahulu diuji kelayakan validitas dan reliabilitasnya. 
Teknik analisis data yang digunakan adalah teknik analisis varian. Karena terdapat interaksi dilanjutkan dengan uji lanjut yang menggunakan uji Tukey. Sebelum data diolah terlebih dahulu dilakukan uji normalitas dan uji homogenitas dengan taraf signifikansi $\alpha=0,05$

\section{HASIL PENELITIAN}

\section{Pengujian Persyaratan Analisis}

Untuk menguji hipotesis, data hasil penelitian diolah dengan menggunakan Analisis Varian (Anava) dua jalan. Sebelum data di analis, terlebih dahulu dilakukan uji persyaratan Anava, yaitu Uji Normalitas dan Homogenitas.

\section{a. Normalitas}

Uji normalitas hasil kemampuan memecahkan masalah lingkungan hidup pada masing-masing kelompok perlakuan dengan menggunakan uji Chi Kuadrat $\left(\mathrm{X}^{2}\right)$ pada taraf kepercayaan atau signifikansi $a=0,05$. Adapun rangkuman hasil uji normalitas dalam penelitian ini dapat dilihat pada tabel berikut.

\section{Tabel 2.}

Rangkuman Hasil Uji Normalitas dengan Uji Chi Kuadrat

\begin{tabular}{|l|l|l|l|l|l|l|l|l|}
\hline & A1 & A2 & B1 & B2 & A1B1 & A1B2 & A2B1 & A2B2 \\
\hline Chi-Square & $17.000^{\mathrm{a}}$ & $12.200^{\mathrm{a}}$ & $15.800^{\mathrm{a}}$ & $20.200^{\mathrm{b}}$ & $10.800^{\mathrm{a}}$ & $9.700^{\mathrm{b}}$ & $6.400^{\mathrm{c}}$ & $4.200^{\mathrm{d}}$ \\
df & 11 & 11 & 11 & 13 & 6 & 8 & 7 & 10 \\
Asymp. Sig. & .108 & .349 & .149 & .090 & .095 & .287 & .494 & .938 \\
\hline
\end{tabular}

Dilihat dari tabel di atas, taraf signifikansi dari hasil uji normalitas dengan $x^{2}$ lebih besar dari a $(>0,05)$ dan $x^{2}$ hitung lebih kecil dari $x^{2}$ tabel. Pada nilai konstruktivis secara keseluruhan (A1) $x^{2}$ hitung $<x^{2}$ tabel $(17,000<19,675)$ dan taraf signifikansi $>$ a $(0,108>0,05)$. Pada nilai interaktif secara keseluruhan (A2) $x^{2}$ hitung $<x^{2}$ tabel $(12,200<$ $19,675)$ dan taraf signifikansi $>$ a $(0,349>0,05)$. Pada nilai kelompok tinggi (B1) $x^{2}$ hitung $<x^{2}$ tabel $(15,800<19,675)$ dan taraf signifikansi $>$ a $(0,149>0,05)$. Pada nilai kelompok rendah (B2) $x^{2}$ hitung $<x^{2}$ tabel $(20,200<22,362)$ dan taraf signifikansi $>$ a $(0,090>0,05)$. Pada nilai konstruktivis kelompok tinggi (A1B1) $x^{2}$ hitung $<x^{2}$ tabel $(10,800$ $<12,592)$ dan taraf signifikansi $>$ a $(0,095>0,05)$. Pada nilai konstruktivis pada kelompok rendah (A1B2) $x^{2}$ hitung $<x^{2}$ tabel $(9,700<15,507)$ dan taraf signifikansi $>$ a $(0,287>0,05)$. Pada nilai interaktif pada kelompok tinggi (A2B1) $x^{2}$ hitung $<x^{2}$ tabel $(6,400$ $<14,067)$ dan taraf signifikansi $>$ a $(0,494>0,05)$. Pada nilai interaktif pada kelompok rendah $(\mathrm{A} 2 \mathrm{~B} 2) x^{2}$ hitung $<x^{2}$ tabel $(4,200<18,307)$ dan taraf signifikansi $>$ a $(0,938>0,05)$. Dengan demikian bahwa sampel berasal dari populasi yang berdistribusi normal.

\section{b. Homogenitas}

Uji homogenitas varians, data skor hasil kemampuan memecahkan masalah lingkungan hidup pada masing-masing kelompok perlakuan dengan menggunakan uji $\mathrm{F}$ pada taraf signifikansi $\mathrm{a}=0,05$. Adapun rangkuman hasil uji homogenitas dalam penelitian ini dapat dilihat pada tabel sebagai berikut 
Tabel 3.

Rangkuman Hasil Uji homogenitas dengan Uji F

\begin{tabular}{|l|l|l|l|}
\hline F & df1 & df2 & Sig. \\
\hline 2.223 & 3 & 76 & .092 \\
\hline
\end{tabular}

Dari tabel di atas diperoleh $\mathrm{F}$ hitung sebesar 2,223 dengan signifikansi 0,092. Sehingga $\mathrm{F}$ hitung $<\mathrm{F}$ tabel $(2,223<2,725)$ dan nilai signifikansi $>$ a $(0,092>0,05)$, sehingga Hipotesis nol diterima. Dengan demikian maka dapat disimpulkan bahwa populasi mempunyai variansi yang homogen.

\section{Pengujian Hipotesis}

Setelah terujinya persyaratan Anava yaitu normalitas dan homogenitas, maka langkah selanjutnya adalah pengujian hipotesis statistik. Pengujian hipotesis statistik dimaksudkan untuk mengetahui apakah hipotesis nol $\left(\mathrm{H}_{0}\right)$ yang diajukan diterima atau ditolak pada taraf signifikansi tertentu. Untuk menguji hipotesis dilakukan dengan teknik Anava dua jalan.

Rincian hasil Anava dapat dilihat ada hasil perhitungan pada tabel berikut

Tabel 4.

Rangkuman Hasil Uji Anava Dua Jalan

\begin{tabular}{|l|l|l|l|l|l|}
\hline Source & $\begin{array}{l}\text { Type III Sum of } \\
\text { Squares }\end{array}$ & $\mathrm{df}$ & Mean Square & F & Sig. \\
\hline Corrected Model & $2630.550 \mathrm{a}$ & 3 & 876.850 & 14.556 & .000 \\
Intercept & 569531.250 & 1 & 569531.250 & 9454.453 & .000 \\
A & 732.050 & 1 & 732.050 & 12.152 & .001 \\
B & 1602.050 & 1 & 1602.050 & 26.595 & .000 \\
A B & 296.450 & 1 & 296.450 & 4.921 & .030 \\
Error & 4578.200 & 76 & 60.239 & & \\
Total & 576740.000 & 80 & & & \\
Corrected Total & 7208.750 & 79 & & & \\
\hline
\end{tabular}

Berdasarkan hasil uji lanjut dengan menggunakan uji Tukey pada taraf signifikansi $\alpha=0,05$. Hasil kemampuan memecahkan masalah pada pembelajaran lingkungan hidup antara siswa kelompok tinggi yang menggunakan model pembelajaran konstruktivis $\left(\mathrm{A}_{1} \mathrm{~B}_{1}\right)$ dengan siswa kelompok tinggi yang menggunakan model pembelajaran interaktif $\left(\mathrm{A}_{2} \mathrm{~B}_{1}\right)$. Dari hasil uji lanjut diperoleh harga qhitung sebesar 5,704, sedangkan harga $\mathrm{q}_{\text {tabel }}$ pada taraf signifikansi $\alpha=0,05$ $(\mathrm{dk}=4 / 80)$ sebesar $<3,74\left(3,74<\mathrm{q}_{\text {tabel }}<3,68\right)$. Ini berarti qhitung lebih BESAR daripada $\mathrm{q}_{\text {tabel}}$, atau ditulis ( $\mathrm{q}_{\text {hitung }}=5,704>\mathrm{q}_{\text {tabel }}=3,74<\mathrm{q}_{\text {tabel }}<3,68$ ) maka dengan demikian $\mathrm{H}_{0}$ ditolak. Ditinjau dari data hasil penelitian pada kelompok tinggi diperoleh harga rata-rata hasil kemampuan memecahkan masalah pada pembelajaran lingkungan hidup antara yang menggunakan model pembelajaran konstruktivis sebesar $\bar{x}=$ 
93,8000 dan simpangan baku sebesar $s=5,65313$. Sedangkan harga rata-rata hasil yang menggunakan model pembelajaran interaktif sebesar $\bar{x}=83,9000$ dan simpangan baku sebesar $s=7,81294$. Ini berarti hipotesis penelitian yang menyatakan bahwa," Hasil kemampuan memecahkan masalah pada pembelajaran lingkungan hidup pada kelompok tinggi terjadi perbedaan antara yang menggunakan model pembelajaran konstruktivis dengan model pembelajaran interaktif." "

\section{E. KESIMPULAN, IMPLIKASI, DAN SARAN}

1. Kesimpulan

Berdasarkan temuan-temuan dan deskripsi data hasil penelitian, pengujian persyaratan analisis dan pembahasan hasil penelitian, maka dapat diambil kesimpulan sebagai berikut :

Hipotesis terbukti. Siswa yang memiliki hasil belajar IPA tinggi, memiliki kemampuan memecahkan masalah lingkungan yang lebih baik setelah melaksanakan pembelajaran pendidikan lingkungan hidup dengan menggunakan model pembelajaran konstruktivis daripada menggunakan model pembelajaran interaktif.

\section{Implikasi}

a. Penerapan Model Pembelajaran dalam Proses Pembelajaran Pendidikan Lingkungan Hidup di Sekolah Dasar.

Langkah-langkah yang bisa di tempuh dalam upaya menerapkan model pembelajaran yang tepat dalam pembelajaran pendidikan lingkungan hidup di sekolah dasar adalah memasukan materi model-model pembelajaran dalam mata kuliah pendidikan lingkungan hidup di LPTK terutama pada mahasiswa program studi Pendidikan Guru Sekolah dasar (PGSD), yaitu pada mata kuliah pendidikan lingkungan untuk sekolah dasar. Hal yang sama juga baik diberikan kepada para guru sekolah dasar yang mengikuti program PLPG dalam rangka sertifikasi guru.

b. Pemanfaatan Hasil Belajar IPA dalam Pembelajaran Pendidikan Lingkungan Hidup di Sekolah Dasar.

Dari hasil penelitian ini, diketahui bahwa dalam pembelajaran pendidikan lingkungan hidup untuk menghasilkan kemampuan memecahkan masalah lingkungan pada siswa, selain diperlukan penggunaan model pembelajaran yang tepat, juga perlu mempertimbangkan faktor hasil belajar IPA.

c. Penggunaan Perfomance Assessment dalam Evaluasi Pembelajaran Pendidikan Lingkungan Hidup di Sekolah dasar

Hasil pembelajaran pendidikan lingkungan hidup di sekolah dasar, umumnya dilakukan dengan penilaian hasil belajar secara kognitif melalui tes tertulis dalam bentuk tes di akhir jam pelajaran, tes formatif atau tes tengah semester atau tes di akhir semester. Penilaian seperti di uraikan di atas kurang tepat, karena keberhasilan pendidikan lingkungan hidup, di antaranya dapat dilihat dari perilaku siswa yang peduli terhadap lingkungannya. Karena itulah maka Perfomance 
Assessment menjadi sangat penting dalam evaluasi pembelajaran pendidikan lingkungan hidup di sekolah dasar.

\section{Saran}

Pertama, model pembelajaran konstruktivis dan model pembelajaran interaktif baik digunakan untuk pembelajaran pendidikan lingkungan hidup di sekolah dasar, agar siswa memiliki kemampuan memecahkan masalah lingkungan yang dihadapinya dalam kehidupan sehari-hari. Maka kepada guru-guru pendidikan lingkungan hidup disarankan untuk menggunakan model-model pembelajaran ini.

Kedua, Selain menggunakan model pembelajaran yang tepat, guru pendidikan lingkungan hidup di sekolah dasar alangkah baiknya juga mempertimbangkan hasil belajar IPA siswa dalam pembelajaran pendidikan lingkungan hidup. Karena hasil belajar IPA yang dimiliki siswa ternyata memiliki pengaruh terhadap kemampuan memecahkan masalah lingkungan sebagai hasil belajar pendidikan lingkungan hidup.

Ketiga para guru pendidikan lingkungan hidup di sekolah dasar, hendaknya juga menggunakan penilaian proses dalam evaluasi pembelajaran pendidikan lingkungan hidup. Penggunaan penilaian proses ini akan membuat guru mengetahui kemampuan memecahkan masalah lingkungan yang dimiliki oleh siswa dalam tataran sikap, bukan hanya dalam tataran pengetahuan saja.

\section{DAFTAR PUSTAKA}

Bell, B.F. Children, Science, Constructivismand Learning in Science. Victoria : Deakin University, 1993

Biddulph, F. Pupil Questioning as a Teaching/Learning in Primary Science Education.Same Papers, Centre for Science and Mathematics Education Research : Hamilton NZ: University of Waikato, 1990

Bruce Joyce dan Marsha Weil.Models of Teaching. London : Pretic Hall International Inc. 1986

Chiras. D.D. Enviroment Science. A Framework For Decision Making. The Benjamin/Cumming Publishing Company, Menlo Park. USA. 1996

Dinas Pendidikan Kota Bandung.Suplemen Kurikulum Muatan Lokal Pendidikan Lingkungan Hidup SD/MI. Bandung, 2008

Heylighen, F. Problem Solving.(on line). Tersedia : http ://www.pesprnc1.uub.ac.be/problem - htm, 2002

Irma Wardhany, Pengaruh strategi pembelajaran lingkungan dan pengetahuan ekologi terhadap kemampuan memecahkan masalah lingkungan, Disertasi PPS UNJ, 2006

Kartadinata, Sunaryo. Studi tentang pengembangan model Pengelolaan Proses Belajar Mengajar yang Mendukung Perkembangan dan Kesiapan Intelektual, Personal dan SosialMurid Sekolah Dasar untuk Memasuki Pendidikan Dasar 9 Tahun. Bandung : UPI. 1999

Kementrian Lingkungan Hidup. Sejarah Pendidikan Lingkungan Hidup di Indonesia. Tersedia : www.menlh.go .id, Jakarta, 2005 
Lieberman, G.A. \& Hoody, L.L.Closing the Achievment Gap: Using The Environment nas an Integrating Context for Learning. San Diego:State Education and Environment Roudtable, 1998

Lucas A.M. Measuring the Succses of Environmental Education Programs. CanadaOntario : canadian Parks and Wildernes Society and Sierra Club, 2002

Marsidi, dkk Pelaksanaan Pengajaran PKLH SD Jawa Barat, Bandung : UPI, 1998

Oktavianty, Resty. Penggunaan Model Konstruktivis Pada Pembelajaran Konsep Cahaya untuk Meningkatkan Aktivitas Belajar Siswa di Sekolah Dasar. Bandung : UPI. 2010

Ria Mey Wulan. Pembelajaran Berbasis Multiple Intelligences untuk Mengembangkan Kreatifitas Berpikir Siswa pada Konsep Perubahan Lingkungan Fisik, Bandung : UPI, 2010

Rush, et al Towards a Set of Principles for Effective Environmental Education Strategies and Programmes and Their Evakuation. Wellington : Agriculture New Zealand Ltd, 1999

Thomas L. Good and Jere E. Bropy, Educational Psychology, A Realistic Approach . New York and London : Longman, 1990

Tobias, S and Hand, B. Developing Constructivist Epistemologies Utilizing a Mentoring Program with Pre-Srevice Primary Mathematics Education Teacher. Educational Studies in Mathematics, 1992

UNESCO. Environmental Education in The Light of the Tbilisi Conference. UNESCO : Paris, France, . 1980

Yuliaritingsih dan Irianto, Pendidikan IPA di Sekolah Dasar. Bandung : UPI. 2008 